\title{
MANDADO DE SEGURANÇA CONTRA ATO PRATICADO EM VIRTUDE DO ESTADO DE EMERGENCIA
}

- Das medidas tomadas em virtude do estado de emergência pelo Chefe de Polícia, não podem conhecer, para apreciá-las, os Juizes e Tribunais.

- Aplicação dos arts. 168, 170 e 186 da Constituição.

\section{PARECER}

$\boldsymbol{O}$ pedido

Alega a requerente :

a) que é uma agremiação regularmente constituída nos têrmos do Decreto-lei n. 4.684 , de 12-9-42, e autorizada a organizar-se e a funcionar pela Portaria n. 6.035, de 6-11-42, do Sr. Ministro da Justiça;

b) que seus fins, indicados no art. $4 .^{\circ}$ dos seus estatutos, devidamente registrados, são lícitos, e ela os vinha exercendo desde a portaria de autorização em aprêço;

c) que, entretanto, em 10 de agôsto do corrente ano de 1944, mandou - Sr. Chefe de Polícia fechar a sede em que a requerente promovia suas reuniões, impedindo o seu funcionamento e apreendendo-lhe os arquivos;

d) que ela requerente, por seu presidente, protestou contra êsse ato do Chefe de Policia, expondo a essa autoridade que a associação só visava fins lícitos e patrióticos, e que a sua ação "se exerceu dentro da mais rigorosa logalidade e as suas atividades se desenvolveram através de reuniő́es públicas, como do conhecimento da Policia" (fls, 12), e que a medida foi tomada antecedendo de um dia a posse do então Ministro das Relações Exteriores em cargo da Diretoria;

e) que a medida adotado pelo Sr. Chefe de Polícia violou direito certo - incontestável da requerente, de funcionar e exercer suas atividades, garantido pelo art. 122, n. ${ }^{\circ} 4$, da Constituição Federal artigos 16, 18, 19, 20, e 21 đo Código Civil : 
f) que ilegal é o ato do Sr. Chefe de Polícia, porque o meio processual idôneo para dissolver sociedades civis que promovam atividade ilícita ou imoral é o indicado no art. 670 do Código de Processo Civil, forma processual esta que não foi observada;

g) que, assim, deve ser concedido à requerente mandado de segurança para que ela possa continuar a "existir como pessoa jurídica (o grifo é da inicial, fls. 16) e funcionar, exercendo as atividades lícitas e altamente patrióticas a que se vinha dedicando.

\section{As razóes do ato}

Ouvida a respeito a autoridade apontada coatora, o Sr. Chefe de Polícia, informou ela, a fls. 153, que "resolveu suspender o funcionamento da referida sociedade, por motivo de ordem e segurança públicas, em virtude do estado de emergéncia decretado pela Constituição, em seu artigo 186".

\section{O art. 122, n. 4 , da Constituiçäo}

O dispositivo constitucional que se dá como violado pelo ato do Chefe de Polícia, o n. 4 do art. 122, deve, de $\log o$, ser afastado da discussão, porque ùnicamente se refere à liberdade de culto teligioso, e de associação para fins de culto. Ora, na hipótese, não se trata de associação religiosa, como se vê. dos estatutos da requerente e da declaração do seu objeto no art. $4 .^{\circ}$ dos mesmos estatutos.

$O$ ato do chefe de Policia e o estado de emergencia - $O$ art. 670 do Código de Processo Civil

Dispõe o art. 186 da Constituição Federal :

"E' declarado em todo o país o estado de emergência"

$\mathrm{E}$ o art. 168 estabelece que durante o estado de emerĝ̣̂ncia são autorizadas ao Executivo as seguintes medidas:

a) detenção em edifício ou local não destinado a réus de crimes comuns; destêrro para outros pontos do território nacional ou residência forçada em determinadas localidades do mesmo território, com privação da liberdade de ir e vir; escritas;

b) censura da correspondência e de tôdas as comunicações orais ou

c) suspensão da liberdade de reunião;

d) busca e apreensão em domicílio;

e) vide lei constitucional n.o 5 .

Se o Sr. Chefe de Polícia informa que resoiveu suspender o funcionamento da associação requerente em virtude do estado de emergéncia, bem se vê que nada tem que ver com o caso o art. 670 do Código de Processo Civil, invocado na inicial. 
Dito artigo sòmente trata da dissolução de sociedades civis, e dissolução durante situações normais, não tendo relação alguma, de modo nenhum, com a suspensão do funcionamento de associações em virtude de e durante o estado de emergência. Aliás, até em situação jurídica normal, em se tratando, como se trata, de associação que depende, para funcionar, de autorização do Govêrno (Decreto-lei n. ${ }^{\circ} 4.684$, de 1942 , citado na inicial), podia êste cassar, até a autorização de funcionamento, conforme o disposto no art. 21, III, do Código Civil, se entendesse que a sociedade incorreu em atos contrários oos seus fins declarados nos estatutos ou prejudiciais ao bem público. $E$ contra êste ato do Govêrno, em situação jurídica normal, os interessados só disporiam - quem o ensina é Clovis Bevilaqua, nas observações 5 e 6 ao art. 21 do Código Civil, - de ação própria (para anular o mesmo ato). Isso, bem entendido, em situação normal, do que no caso não se trata.

Durante o estado de emergência, e em virtude dêle, pode o Govêrno suspender o exercício do direito de reunião e, a fortiori, o funcionamento de associações, notadamente quando êste funcionamento implique, de necessário, no exercício do referido direito, inseparável dos fins da associação.

Ora, de sua natureza, e dos seus próprios fins declarados nos estatutos, e da própria resenha de suas atividades, junto aos autos em folhetos, se verifica que a atividade principal da associação em aprêço consiste no exercício da liberdade de reunião, e que, sem êsse exercício, a associação não poderia, até, preencher seu, fins; e é seu mesmo digno ve ilustre presidente quem, no protesto que dirigiu ao Chefe de Polícia, acentuou, referindo-se à associação em aprêço, que "suas atividades se desenvolveram através de reuniōes públicas, como do conhecimento da polícia" (fls. 12).

De fato, estas reuniōes, ou se realizem na sede da associação, ou ao ar livre (a céu aberto, como diz a Constituição), constituem o meio para o exercício das atividades da associação, e se acham de tal modo ligadas ao funcionamento dela que, para suspendê-las, foi e é necessário suspender o funcionamento da própria associação; e foi nessa suspensão que consistiu, de acôrdo com as informaçóes, a medida adotada pelo Sr. Chefe de Polícia.

O direito de associação, pôsto que distinto do de reunião, é intimamente relacionado con o mesmo, e, não raro como no caso, de tal forma que, para suspender a liberdade de reuniáo, é necessário suspender o funcionamento da associação.

Sôbre essa relação íntima e de dependência entre as duas liberdades, dános justa iđéia o inciso $8 .^{\circ}$ do art. 72 da Constituição de 1891, que tratava conjuntamente das duas liberdades. O fato é, aliás, assinalado pelos constitucionalistas. Entro êstes pode lembrar-se CARLos MAXIMILIANo, que, apoiado em Duguit e ORBAN, frisa essa relação intima entre os dois direitos, dos quais um é, não raro, conseqüência do outro. A Constituição americana, escreve êste notável mestre, nem sequer trata do direito de associação, abrangendo-o os comentadores no direito de reunião (Comentários, 1918, p. 696). E DuguIr (Manual, 1923, págs. 241 e 283) assinala que, quando as associações tomam o caráter de clubes, são antes reuniões que associações (ne son pas de véritables associations, mais bien plutôt des réunions), "formadas para manter e provocar periòdicamente reuniões de caráter político" (claro que o político, aí, não se acha empregado só em sentido estrito - de política partidária). Pouco importa, pois, a denominação - sociedade; - o que importa é a realidade e não o nome. $\mathrm{Na}$ hipótese, trata-se de uma associação em que os associados se admitem em número ilimitado, por simples adesão, mediante insignificante entrada em dinheiro, e essa associação realiza seus objetivos mantendo e piovocando reuniōes com fins políticos (emprêgo em sentido lato), conforme, aliás, o certifica a resenha de suas atividades. Nestas condiçóes, ela se apro- 
xima daquele tipo de associaçōes que, à semelhança dos clubes, como escreve DuGurT, são antes manifestações da libendade de reunião que verdadeiras associações.

Mas, basta que seu funcionamento, como diz o seu ilustre presidente, se realize através de reuniōes, para que possa êsse mesmo funcionamento ser suspenso, durante o estado de emergência, nos precisos têrmos do art. 168, letra $c$, da Constituição Federal.

Demais, repugnaria ao simples bom senso que, em estado de emergência, quando o Govêrno pode deter e até desterrar as pessoas (o que nos E. E. Unidos corresponde à suspension of the privilege of the writ of habeas-corpus), isto é, tomar-lhes tôda a liberdade, não pudesse limitar-se a tomar uma parte dessia liberdade, suspendendo o funcionamento de uma associação (a que o ilustre advogado da requerente denomina muito acertada e significativamente de agremiação), isto é, suspendendo a sua faculdade de manter e provocar reuniōes (que se inclui na liberdade de ir e vir), quando, como diz expressamente o dispositivo constitucional, o País se acha em estado de emergência, e uma das conseqüências dêsse estado é o poder o Govêrno suspender a liberdade de reunião segundo o seu critério e discrição.

Menos se compreenderia, ainda, que, em se tratando, como se trata, do associação ou grêmio que depende de autorização para se constituir (conforme, aliás, reconhecido na inicial, pela requerente, que pediu e obteve, em 1942, dita autorização), não possa o Govêrno, em estado de emergência e usando dos poderes de que se acha investido em virtude dêle pela Constiturição, - suspender o funcionamento da associação, quando podia, até, simplesmente, cassar a autorização concedida e, por esta forma, mais que suspender, dissolver, até, a associação em aprêço, independente de processo.

Claro é que as formas jurídicas processuais foram feitas para tempos normais. Para dispensá-las é que se decreta o estado de emergência ou o estado de sítio. E' para isso que serve o estado de emergência. Se não, a que serviria?

Também para deter pessoas há processos na lei; mas ninguém dirá que tal processo deva ser observado em estado de sítio ou de emergência. Para deter pessoas, suspender reuniōes, dar busca em domicílio, mediante as formas normais do processo, o Govêrno não necessita do estado de emergência. Se decreta êste, é justamente para suspender as formas do processo para os atos que o estado de emergência autoriza praticar (MAXIMILIANo, adiante citado)

\section{$O$ chefe de Policia e o estado de emergência}

Não se nega, nem jamais se contestou, por centenas de vêzes tem sido reconhecido por êste egrégio Tribunal, como pelo egrégio Supremo Tribunal Federal, que o Chefe de Polícia tem poderes para tomar medidas em virtude do estado de emergência. As colendas Câmaras Criminais, do mesmo modo que o Supremo Tribunal, com efeito, em inúmeros acórdãos, sempre admitiram, indiscrepantemente, desde 1937, e através da administração de vários Chefes de Polícia, a existência dêsses poderes, tanto assim que, quanto ao mais grave dêles, o de deter pessoas, não têm conhecido, sistemàticamente, dos pedidos de habeas-corpus em favor dos detidos, desde que o Chefe de Polícia informe que, por autoridade dêle, o paciente se acha prêso por motivo de ordem de segurança pública, em virtude do estado de emergência. E por que tem sido assim? Porque as detenções, as entradas em domicilio, as suspensões da liberdade de reunião, e os mais atos compreendidos no art. 168, letra a a e, da Constituição, isto é, atos praticados em virtude do estado de emergência, são atos de polícia, que ao Chefe de Policia do Distrito incumbe praticar, como 
agente imediato do Govêrno, preposto à Chefia e orientação da Polícia. Essa autoridade é, tàcitamente, naturalmente, por fôrça de suas próprias funções, o órgão do Govêrno executor das medidas ditadas pelo estado de emergência, no Distrito Federal. Suas atribuições, para executar tais medidas, resultam de um mandato legal, da lei que lhe dá funções e atribuições de usar do policepower. Tanto isto é certo que, em querendo reservar ao Presidente da República a faculdade de praticar atos em virtude do estado de guerra, foi necessário que o Decreto n. ${ }^{\circ} 10.358$, de $31-8-42$, que proclamou o estado de guerra, fizesse expressa ressalva, verbis : "Só o Presidente da República tem o poder de diretamente, ou por delegação expressa, praticar atos fundados nesta lei" (art. 2. ${ }^{\circ}$, parágrafo único), continuando, porém, como dispõe o mesmo parágrafo, a delegação tàcita, ou, melhor, a atribuição legal do Chefe de Polícia, de praticar atos em virtude do estado de emergência.

Mais acentuou essa atribuição o Decreto-lei n. 6.378 , de 28-3-44, que transformou a Polícia Civil do Distrito Federal em Departamento Federal de Segurança I'ública, a cujo cargo ficaram, no Distrito Federal, "os serviços de polícia e segurança pública" (art. $2 .^{\circ}$ ), coopenando dito Departamento com as Polícias dos Estados especialmente quando interessada a segurança do Estado e a estrutura das instituições. Aos próprios Chefes de Polícia dos Estados reconheceu o Supremo Tribunal essa atribuição de praticar atos incluídos nơ poderes do estado de emergência, como se vê do acórdão no h. c. n. ${ }^{\circ} 28.313$, in Diário da Justiça, de 3-7-43, acórdão que, por unanimidade, negou habeas. cozpus a paciente prêso, à vista de haver o Chefe de Polícia da Bahia informado que a prisão de dera "por motivo de ordem e segurança pública" (vide pág. $2.828,1 .^{\mathrm{a}}$ coluna, in princ.).

Mas, não há por que insistir no ponto, à vista da, como já disse, jurisprudência absolutamente constante dêste Egrégio Tribunal e do Egrégio Supremo Tribunal Federal.

\section{O judiciário não aprecia atos praticados em virtude do estado de emergência} - A quem compete a apreciação

Esclarecido êste ponto - de caber nas atribuições do Chefe de Polícía praticar os atos em virtude do estado de emergência, admitamos, por um momento, para argumentar:

a) que se pudesse pôr em dúvida que o ato em aprêço estivesse autorizaco peto art. 168, isto $e$, que o Chefe de Policia tivesse excedico os poderes que ao Executivo confere o mesmo artigo;

b) que se pudesse pôr em dúvida tivesse o ato relação com a ordem e segurança pública, in facto.

Ainda assim, para que se pudesse cogitar da concessão de mandado de segurança contra medidas de segurança tomadas em virtude do estado de emergência, seriam necessárias duas condições simultâneas : $10^{\circ}$ que o ato incriminado fôsse manifestamente contrário ao dispositivo constitucional em aprêço, isto é, que excedesse manifestamente os poderes por êle concedidios a.o Chefe de Polícia, isto é, que evidentemente tivesse to Chefe de Polícia cometido abuso, com "suspender o funcionamento" da associação, isto é, com impedir que a associação continuasse a reunir-se ou promover reunióes, quer no ar livre (a céu aberto), quer no interior da sua sede. Em 2..$^{\circ}$ lugar, para o mandado de segurança, necessário seria que o direito da agremiação de continuar a promover reuniões entre os seus agremiados, ou na praça pública, ou em outros locais; constituísse para ela, em face do estado de emergência e dos poderes de que dispóe o Govêrno no art. 168, um direito certo e incontestável. Tudo isso é do art. 319 do Código de Processo Civil: são os pressupostos taxativos do mandado de segurança. 
Ora, diante do texto do art. 168 , que permite a detenção, até, de pessoas quaisquer, como permite a suspensão do exercício do direito de reunióes, realmente impossivel admitir-se que uma agremiação, cuja atividade principal é necessàriamente exercida por meio da promoção de reuniões, tenha direito certo e incontestável de funcionar, nem que o Govêrno, suspendendo êsse funcionamento, tenha violado manifestamente o dispositivo do art. 168 .

Mas, já o mostramos, e não é necessário insistir no ponto, - que o ato, pelo contrário, se conteve nos limites dos poderes discricionários concedidos no art. 168 .

Tanto, porém, na 1.a hipótese - ter a Polícia excedido o poder que lhe confere o art. 168, como na $2 .^{\mathrm{a}}$ - de não se relacionarem os motivos da suspensão à ordem e segurança pública, - em qualquer dessas hipóteses, e aqui a razão é terminante, e aqui se acha o ponctum pruriens da questão - tôda ela de direito público constitucional, de direito politico _- em qualquer dessas hipóteses, o executor do estado de emergência tẹria incorrido em excesso de que o Poder Judiciário não pode conhecer e de que lhe falece competência para julgar, quer direta, quer indiretamente, dưrante o estado de emergência.

Quem isso diz é a literal disposição do art. 170 da Constitutição invocada pela requerente, que reza, verbis :

Art. 170. Durante o estado de emer gência, ou o estado de guerrạ, dos atos praticados em virtude dêles, não poderão conhecer os jứzes e tribunais".

Não conhece está, no dispositivo, no sentido de não apreciat, como notou - Sr. Ministro CASTro NunEs. Visando subtrair à apreciação, ao exame, à ceecisão dos Tribunais os atos praticados em virtude do estado de emergência, ou de guerra, não se limitou a Constituição a vedar a apreciação dêles pelós Tribunais; empregou uma expressão mais enérgica : Não conhecer, não entrar de forma alguma ou sob nenhưm pretexto na apreciação dêles, desconhecế-los, ignorá-los.

E por que não devem conhecer de tais atos os Tribunais, durante o estado de emergência? A resposta está no próprio texto constitucional.

Os Tribunais não poderão conhecer dêsses atos, não poderão apreciá-los, não poderão examinar os seus motivos, a oportunidade, a discrição, a conveniência, de qualquer dêles, o excesso que acaso encerrem, porque tudo isso escapa à atribuição do Poder Judiciário para cair na do Poder Legislativo. Trata-se de atos de polícia, trata-se de matéria política, exclusivamente, e os Tribunais não podem conhecer de questões exclusivamente políticas (Constituição, art. 94).

Tais atos do Executivo escapam ao juizo judiciário, durante o estado de emergência, - é o que diz o art. 170 , - porque êsse atos, de natureza exclusivamente política, ficam sujeitos ao jứzo político da Câmara dos Deputados, que é o órgão competente para lhes apreciar a oportunidade, a conveniência, a legitimidade dos seus motivos.

E' O que está claramente expresso no art. 167 da Constituição:

"Cessados os motivos que determinaram a declaração do estada de emergência ou do estado de guerra, comunicará o Presidente da República à Câmara dos Deputados as medidas tomadas durante o período de vigência de urm ou de outro.

Parágrafo único. A Câmara dos Deputados, se não aprovar as medidas, promoverá a responsabilidade do Presidente da República, 
ficaño a êste salvo o direito de apelar da deliberação da Câmara para o pronunciamento do País, mediante dissolução da mesma e a realização de novas eleições".

Por que ficam os atos sujeitos ao juízo político da Câmara? Porque a Câmara é o grande júri dos atos do Executivo, é o juízo da acusação, da mise on accusation do Presidente, é, em suma, o juízo do impeachment. Se a Câmara não aprovar as medidas, acusará o Presidente perante o Conselho Federal (art 86). Imposta a pena de perda do cargo, por êste, abrir-se-á é então ensejo ao pronunciamento do Judiciário, no ć́vel como no crime, contra os agentes do Executivo (art. 86, \& $10^{\circ}$ ).

Se a Câmara, porém, aprova os atos, nenhum outro juízo pade apreciá-los e julgá-los, sobrepondo-se ao julgamento dela, salvo quanto ao cível, observado - art. 1.525 do Código Civil.

Do contrário ficariam os ditos atos sujeitos a dois juízos igualmente soberanos : o do Poder Judiciário e o da Câmara e Conselho Federal.

\section{Jurisprudência a respeito}

A jurisprudência é, também, neste ponto, indiscrepante.

Requerido habeas-corpus, ou mandado de segurança, o judiciário não os repele in limine, porque, como o salientou CASTRo NUNES, comentando o acórdão do Supremo Tribunal abaixo citado (Arq. do $M$. da Justiça, n.o 3, p. 1), Esses meios ou vias judiciais não estão suspensos; conhece dêles o Judiciário para processá-los, e para, processando-os, mandar ouvir a autoridade apontada como coatora. - Se esta informa que o ato - a detenção, ou outra medida - foi praticado em virtude do estado de emergência, então o Judiciário, não podendo conhecer dessas medidas, apreciar-lhes os motivos, a conveniência, a oportunidade, ou se elas se relacionam realmente com o estado de emergência, com a manutenção da ordem e segurança pública (porque essa apreciação cabe à Câmara e ao Conselho Federal depois de cessado o estado de emergéncia), nega, prejudicialmente, a ordem de habeas-corpus ou o mandado de segurança, ou dêles não conhece por the faltar competência para apreciar o ato da autoridade coatora.

No ponto fol unánime o acớdáo do egréglo Supremo Tribunal Federal, no habeas-corpus n. ${ }^{\circ} 28.313$ (Diário da Justiça, de 3-7-43), aresto que negou a ordem à vista da informação do Chefe de Polícia da Bahia, de ter sido a prisão efetuada por motivo de ordem e segurança públicas.

Claro está que o que tem lugar nos habeas-corpus, tem lugar nos mandados de segurança, como tem lugar em qualquer medida judicial contra os atos praticados em virtude do art. 168 da Constituição. E' o ato que escapa à apreciação judiciária, qualquer que seja o meio ou recurso processual mediante o qual é êle trazido à apreciação dos Tribunais.

De tudo o acima exposto resulta que, se a autoridade informa, nos pedidos de h. c., que a detenção foi feita em virtude do estado de emergência por motivo de ordem e segurança públicas, jamais, em caso algum, tanto o egrégio Supremo Tribunal como êste egrégio Tribunal de Apelação mandaram ou mandam indagar do coator qual a relação de causalidade porventura existente entre a ordem e segurança públicas e a detenção do paciente. Indugar da relação existente entre o ato da autoridade e a ordem pública é que é, precisamente, fazer o que o art. 170 da Constituição veda expressamente: isto é, conhecer do ato praticado em virtude do estado de emergência, examinar o ato, 
verificar os seus motivos de fato, se êle foi excessivo ou não, oportuno, ou não, matéria tôda esta que fica ao juizo exclusivo da autoridade, a seu critério. Só a autoridade sabe e decide se e até que panto uma determinada detençäo (art. 168 a), a censura de uma carta (artigo $168, b$ ), a suspensão de determinadas reuniōes (art. 168, c) ou determinada busca em domicílio (art. 168, d), praticadas em estado de emergência, são úteis, aproveitam, ou não, à ordem e segunança públicas. Nesse terreno o juízo do Executivo é discricionário; e êssé é o terreno vedado ao exame, ao conhecimento, à apreciação do Judiciário, na forma do art. 170. Esses assuntos constituem matéria exclusivamente política sujeita ao juízo discricionário do Executivo, salvo sua prestação de contas ao juízo político da Câmara dos Deputados (art. 167 e parágrafo único) (cf. CASTro NuNES, in Arquivos, cits.).

O ponto é, aliás, incontroverso, na jurisprudência.

E' assim que, quando das detençōes de pessoas por motivo do estado de emergência, solicitadas informações, o Chefe de Polícia (não só o atual, mas todos os seus antecessores), se limita a informar que a detenção foi feita por motivo de ordem e segurança públicas, e, invariàvelmente, de nada mais indaga o Tribunal (tanto o de Apelação como o Supremo), para decidir, como tem decidido, não conhecer do pedido por ter sido o paciente prêso por motivo de ordem e segurança públicas; segundo informa o Chefe do Polícia.

E se assim é, e assim tem sido, sem exceção, quanto aos atos mais graves a que se refere o art. 168, isto é, quanto às detençōes, autorizadas na letra a do mesmo artigo, claro é que assim também há de ser, nos atos menos graves, autorizados nas letras $b, c, d$ e e. E' que, no art. 170 , o que a Constituição veda é o exame, a apreciação de todos e quaisquer atos praticados em virtude do ert. 168, e näo apenas dos praticadas com base na letra a do mesmo artigo.

\section{A informação do Chefe de Polícia}

Nestas condições, a informação do Chefe de Polícia, de fls., obedeceu rigorosamente aos têrmos constitucionais: êle não tinha, realmente, que informar os motivos pelos quais o funcionamento da agremiação, a promoção de suas reuniōes, foram reputados inconvenientes à ordem e segurança públicas; êstes motivos de ajuizar são dêles, e, se no exame dêles não podem entrat os Tribunais, por fôrça do imperativo do art. 170, evidente é que sôbre êles não havia de alongar-se a informação. - E, mais que isso, nem mesmo pode o Chefe de Polícia sujeitar o seu ato à apreciaçáo dos Tribunais, revelando os motivos pelos quais êle interessa à ondem - segurança públicas: como agente do Poder Executivo, incumbe-lhe reservar os seus motivos até que, cessado o estado de emergência, dos atos seja feita prestação de contas ao Júizo político competente (art. 167). E, de outro lado, en face do art. 170, eos Tribunais, que não têm atribuição para conhecer dos atos praticados em virtude do estado de emergência, também, evidentemente, não cabe indagar das razóes dêsses atos, desde que cientes de terem êles sido considerados, pela autoridade que os praticou, necessários ou úteis à ordem e segurança públicas, que ao Executivo incumbe manter.

Se assim não fôsse, fácil seria imaginar as absurdas consequiências que dai decorreriam; tôda vez que se censurasse uma carta (artigo $168, b$ ), em vindo a parte a Juízo, o Judiciário mandaria saber do Exacutivo por que censurou a carta destinada ao cidadão Fulano, por que era ou é suspeito êsse cidadão, em que a censura das cartas dirigidas ao mesmo cidadão interessa à manutenção da ordem pública... Tôda vez que se detivesse umá pessoa (art. 168, a), vindo ela a Júzo, o Judiciário passaria a indagar do Executivo por que razão detenção dessa pessaa interessa à ordem pública; e o Executivo seria obrigado 
a dar a razão, por exemplo - que êsse cidadão estava conspirando, que a conspiração ena mais ou menos séria, pois abrangia tais e tais pessoas, etc.; suspensta uma reunião, e ajuizada uma medida qualquer contra o ato, passaria o Judiciário a fazer indagações da mesma natureza; censurado um artigo dêste ou daquele jornalista (art. 168, $b$ ), o Judiciário entraria no exame do artigo, mandaria perguntar ao Executivo que é que no escrito foi reputado perigoso à ordem política e social... e assim por diante, de modo que, imiscuindo-se a Justiça neste assuntos, breve teríamos não já um só, mas dois executores do estado de emergência, e, até, do de guerra: o Executivo e o Judiciário, quando não a sub-rogação dêste nas funções próprias e privativas daquele. $E$, o que é mais grave: o Executivo ficaria obrigado a revelar pùblicamente tôdas as medidas que tivesse tomado e suas circunstâncias e motivos, e o Judiciário passaria a julgar do critério, da necessidade e da conveniência delas, o que é, precisamente, o que veda o art. 170. Nãó haveria reserva alguma na atuação policial: bastaria o recurso ao Judiciário para constranger o Executivo a trazer a público tudo o que a Polícia descobrisse com relação às conspirações, aos planos sediciosos, aos suspeitos, e tudo o mais. Não haveria, no mundo, polícia que se pudesse manter, num tal regime. Não escapariam nem as medidas tomadas, não já em virtude do estado de emergência, mas do próprio estado de guerra, porque o art. 170, que regula as relaçóes do Executivo com o Judiciário, durrante a emergência, é o messno que regula essas relações, durante a guerta.

\section{$A$ apreensão}

Alega a requerente ter sido feita busca e apreensão, em seu domicílio ou sede, dos arquivos. - Mas êsse é outro ato autorizado expressamente pelo estado de emergência, no art. 168 , letra c, da Constituição:. "c) busca e apreensão em domicílio."

Tudo o que ficou dito e o que se segue a respeito da suspensão, do funcionamento da associação em aprêço se aplica, integralmente, a êste ato de apreensão.

Claro está que a autoridade executora do estado de emergência não é obrigada a justificar, no Judiciário, em que, ou como, ou por que motivo a apreensão interesse à ordem e segurança públicas; nem o Judiciário tem atribuição para conhecer dêsse ato de apreensão, pesar-lhe os motivos, julgar tus razóes. O contrário seria invadir o Judiciário, contra o disposto no citado art. 170, a esfera de competência política privativa do Executivo, para, tôdas as vêzes que êste procedesse a uma busca e apreensão domiciliar por motivo reputado interessante à ordem e segurança públicas, constrangê-lo a vir, a requerimento de parte, ao Tribunal ordinário, estando o País em estado de emergência, exibir os papéis, os livros, os arquivos, os documentos apreendidos, para demonstrar que, de fato, a medida interessava à ordem política.

Não há no mundo Constituição que admita semelhante coisa.

Nem a Constituição de 1934, no seu art. 175, tolerava isso. - As medidas enumeradas nas letras a e e do n. 2 dêste seu artigo, autorizadas durante - sítio, são idênticas às enumeradas no art. 168 da Constituição de 1937. Daí - ser o nosso estado ide emergência correspondente ao antigo estado de sítio. Pois bem: durante o sítio, de acôrdo com essa Constituição, não podia o Judiciário entrat na apreciação das medidas tomadas, cabendo a mesma à Câmara ( $\$ \$ 12$ e 13 ) :

"A Justiçă não poderá dizer, comentava Pontes de MIRANDA, se são legais ou não as medidas tomadas durante o sítio - desde que caibam, rigoroamente, no art. 175,2 ), - antes de aprovar-lhes as providências o Poder Legislativo ou a Câmara dos Deputados"' (Const. de 1934, II, pág. 513). 
E tratava-se de uma Constituição cujo liberalismo superava o de 1891 , e que, ao primeiro contato com a realidade, obrigou o Congresso à modificação do seu art. 175, mediante a emenda $n .^{\circ} 1$, de 18 de dezembro de 1935 , armando o Erecutivo de mais amplos poderes.

\section{Os motivos do executivo são insindicáveis pelos tribunais}

Em vão, portanto, pretende a requerente aprecie o Poder Judiciário o ato do Executivo, procurando infirmá-lo com as alegações da regularidade com que ee constituiu em 1942, ou de que até o ex-Ministro do Exterior, a cujo respeito todos subscrevemos os conceitos que emitiu o Govêrno transcritos na inicial, fls. 8 e 9, nela aceitara cargo de diretoria, ou de que outras autoridades a ela haviam aderido, ou de que suas reuniōes eram públicas. Tôda essa matéria como a dos motivos que teria tido o Executivo para a suspensão resolvida, escapa inteiramente à apreciação do Tribunal, em face da terminante disposição do art. 170 da Constitưição:

\section{Aliás:}

a) do fato de se ter constituído regularmente agremiação em 1942 não se segue que o Executivo possa ou não tenha motivos para, em 1944, e nos têrmos do artigo 168 da Constituição, suspender o seu funcionamento, as suas reunióes, ou apreender os seus arquivos;

b) do fato de fazerem parte da associação várias pessoas e até autoridades, maiores de qualquer suspeita, e em quem o Govêrno continuou e continua a depositar confiança, não se conclui que, por fatos cuja apreciação só ao Executivo cabe ( art. 170) e cuja apuração e conhecimento the pertencem, nāo possa o mesmo Executivo suspender o seu funcionamento; essas pessoas não podem sequer conhecer, um a um, todos os numerosos agremiados, para fazer dêles, ou de sua atuação, juizo seguró; e jửem não estar a par doe fatos em que o Executivo se baseou para tomar a medida. Relacionar a medida a essas pessoas, seria dar curso ao defeito de lógica - post hoc, ergo propter hoc; aliás, da resenha das atividades da agremiação, junto aos autos, consta que desde dezembro de 1943 (fls. 46 v. ), já a associação fôra submetida a censura total. Isto prova que, bem antes do ato de suspensão (que é de 10 de agôsto de 1944), já o Govêrno, pelo órgão competente para executar a censura decorrente do estado de emergência, havia manifestado, pùblicamente, a sua desaprovação a algumas das atividades da associação em aprêço;

c) do fato de ainda em março de 1944 (fls. 142) vir submetendo o ilustre Presidente da associação as listas dos novos aderentes à consideração da Polícia não se deduz necessàriamente o que se teria passado de março a agôsto do mesmo ano, nem que antes ou depois de março não tivesse a autoridade apurado fatos que justifiquem a efetivação da medida que adotou.

Como quer que seja, não é, forém, demasia repetit que o exame do ato sob o aspecto de sua oportunidade, motivação, conveniência, escapa; por compieto, ao Júizo do Tribunal, pois, já no regime de 1891, "Tratando-se de ato político, não é licito ao Podet Jứiciário entrat na apreciação dos fatos e motivos que o determinaram, sob peria ciz abuso de poder, a menos que o poder Executivo the preste contas dos interrosatórios e inquétitos abertos para apurar a responsabilidede dos suspeitos... direito reservado exclusivamente ao Congresso Nacional pela Constituição". . (acórđão do Supremo Tribunal de 14-1-1925). 


\section{o sitio e o judiciário na Constituição de 1891, e na reforma em 1926}

$O$ alheamento dos Tribunais Judiciários ao exame de atos do Executivo em virtude do estado de sítio, ou de emergência, alheamento consagrado no art. 170 da Constituição de 1937 , não representa, ademais, nenhuma novidade. $O$ princípio é universal e constante, como é fácil verificar.

RUI BARBosa, para invocar o testemunho do mais acatado e do mais liberal dos nossos constitucionalistas de 91, versando diretamente a questão, embora o maior adversário do sítio (e o estado de emergência do art. 168 da Constituição de 37 é o mesmo estado de sítio das antigas Constituiçõos; o art. 168 , adotando o critério da Constituição de 1934, art. 175 , veio apenas cortar as dúvidas reinantes na vigência do art. 80 da Constituição de 91 sôbre quais as garantias que ficam suspensas : cfr. art. 168 da Constituição de 1937 com o art. 175 da de 1934 e 80 da de 1891), Rui Barbosa, depois de aludir ao mandato tácito ou presuntivo do Legislativo ao Executivo para decretar e executar o sítio, escreveu :

"Como delegado, logo que se reunir o Congresso. The relatará, motivandoas, as međidas de exzcução (art. $80,833^{\circ}$ ).

" $E$ se, na sua aplicação, se houver demasiado, responderá pelos abusos cometidos" ( $\$ 4 .^{\circ}$ ).

E continua, invocando a ALCORTA :

"Pude suceder, diz Alcorra, que o Executivo, estando, cono o está, autorizado a decretar o estado de sítio, abuse da faculdade, estabelecendo-o sem a mínima causa daquelas exigidas, e prenda as pessoas e disponha das coisas com desígnios estranhos aos objetivos da medida; e pode suceder também que deternine medidas que não são autorizadas, condene e reieve penas..

Qual será a consequêencia? Que remédio terá tudo isto? A medida (o sítio), e suas aplicações são sem dúvida discricionárias, mas o são nos limites que a Constituição a seu respeito fixou... Assim, nos casos a que nos referimos, existe responsabilidade e se faz efetiva peio Juízo Politico" (RuI, Comentários à Constitutição de 91 , vol. VI, pág. 337).

"A intervenção das Câmaras no conhecimento do estado de sítio decretado no intervalo parlamentar corresponde a fins não menos óbvios que êstes :

- remover, ou manter o estado de sítio, se perdura; cacias; conhecer da correção do procedimento do Govêrno nas medidas apli-

- submeter os órgãos do Poder Executivo à responsabilidade constitucional pelos excessos"' (Ibidem, pág. 338).

E é esta a prática consagrada, acrescenta Rur :

"Em tôdas as legislações modernas, desde a da Inglaterra até à dos Estados Unidos, desde a da Itália até à da França, desde a da Austria até à da Alemanha, desde a do reino de Portugal até à do Império do Brasi', desde a da República Argentina até à do Uruguai, desde a Boliviana até à Paraguaia". (pág. 338).

E, mais claramente (pág. 292), contestando a autoridade do Executivo para demitir em virtude do sítio do art. 80 da Constituição de 91 :

"Discricionário, político, é o poder do Presidente da República (por êle ou seus delegados dizemos nós), prendendo e destersando, no decurso do estado de sítio; porque a Constituição the confere a autoridade política, discricionária (o grifo é do autor) de prender e desterrar. $E$ da sua discrição no 
emprêgo dessa medida política o Congresso, como autoridade política, especificadamente proposta a êsse encargo (Constituição, art. $34, n^{\circ} 21$ ) é o único Juiz"'.

Note-se que a Constituição de 1891 não continha explícito o princípio hoje expresso no art. 170 da Constituição de 1937.

Não obstante, o princípio se achava implícito, e assim o considerava Rur, como tơdos os constitucionalistas. E a jurisprudência do Supremo Tribunal sempre consagrou essa doutrina, através de numerosos arestos que vêm desde a aurora da República, desde 1892 .

Eis o que a respeito firmou o acórdão de 1892, em habeas-corpus a requerimento de Rui (êste pleiteava que, tendo cessado o estado de sítio, cessavam as prisões por motivo dêle) :

"Pelo art. 80 , \$ $3 .^{\circ}$, combinado com o art. $334, \$ 21$, da Constituição, ao Congresso compete privativamente aprovar ou reprovar o estado de sítio declarado pelo Presidente da República, bem assim o exame das medidas excepcionais que êle hourver tomađo, as quais para êsse fim the serão relatadas com especificação dos motivos em que se fundam.

Antes, portanto, do júzo politico do Congresso, não pode o Poder Judiciário apreciar o uso que fêz o Presidente da República daquela atribuição constitucional. Também, não é da índole do Supremo Tribunal Federal envolver-se nas funções politicas do Poder Executivo ou Legislativo. Ainda quando, na situação criada pelo estado de sítio, estejam ou possam estar envolvidos alşuns direitos individuais, esta circunstância não habilita o Poder Judiciário a intervit para nulificar as medidas de segurança decretadas pelo Presidente da República, visto ser impossivel isolat êsses direitos da questão política que os envolve..." (acórdäo de 27-4-1892).

Essa doutrina é a mesma dos acórdãos de 1-9-1894, 26-3-1898, 16-4-1898 e 4-3-1905.

Um dos arestog mais fundamentados, a respeito, é o acórdão de 15-4-1914, onde se lê que: "é princípio cardial do direito constitucional, relativamente ao exercício dos poderes públicos, armados de igual independência, quanto às suas funções privativas, que uma vez expressamente conferida a um dêles uma atribuição para a prática de dado ato ou para uso de dada faculdade, é êle o único juiz competente da oportunidade e das razões determinantes do respectivo ato ou do uso de sua faculdade; porque o contrário seria a negação completa da sua independência".

Ainda o acórdão de 25-4-1914 : "Conforme a doutrina e a jurisprudência do Supremo Tribunal, não cabe ao Judiciário julgar dos motivos e razōes que teve o Presidente da República para decretar o estado de sítio e tomar medidas de segurança que a Constituição autoriza".

No mesmo sentido, o acórdão de 9-5-1914. bem como o de 10 de junho de 1914, em que, referindo-se à competência para apreciar as medidas adotadas durante o sítio, se disse: "Tanto poder tem o Judiciário para tal, como teriam o Legistativo ou o Exectrtivo para opor-se à execução dos julgados da Justiça a pretexto de que êstes não assentam em prova legal ou suficiente".

Ainda nos acórdãos de 30-4-1923, 1-10-1923 e 21-7-1924, não variou êsse tradicional modo de julgar.

No acórdão de 16-10-1922, firmou-se mais uma vez essa doutrina, e de tal forma a jurisprudência do Supremo a sancionou que, quando veio a reforma Constitucional de 1926, que acrescentou ao art. 80 da Constituição de 1891 dispositivo igual ao do art. 170 da Constituição de 1937, pôde dizer HermeNESLL DE BARROS que "isto não é uma novidade para o Supremo Tribunal, que, por maiotia poderosa, compacta, esmagadora, já não conhecia dos atos 
praticados pelo Poder Executivo durante o sítio, por entender que dos abusos porventura cometidos por êle só o Legislativo poderia tomar conhecimento".

E acrescenta :

"A reforma nem sequer admite discussão sôbre tais atos : não permite que - Poder Judiciário os examine, as aprecie, e os declate constitucionais ou inconstitucionais" (Memórias, vol. VIII, pág. 85).

E' o que também se pode dizer do atual art. 170 : êle não trouxe novidade alguma : já estavia na doutrina, como na jurisprudência dio nosso mais alto Tribunal, e já havia sido consagrado pelo Congresso na reforma Constitucional de 1926, que incluiu o princípio, por expresso, no art. 80 da Carta de 1891 .

Antes de reforma, já escrevia Maximniano (Constituição, número 300), referindo-se às detenções :

"Não se entrega nota de culpa, não se explica o motivo pelo qual a suspeito é isolado ou removido. E' exatamente para isso que se decreta o estado de sitio".

"O estado de sítio é decretado para isso; para armar o Executivo do direito de deter os suspeitos, sem nota de culpa, sem figura alguma de juízo. Porque prender um rebelde dando as razóes por que o prende pode-se fazê-lo em regime normal, sem estado de sítio, como fêz Campos Sales com Andrade Figueira" (ibidem, pág. 830).

Da mesma forma : para suspender o funcionamento de uma associação, dando as razões, não se precisaria de estado de emergência. Já o art. 21, III, do Código Civil confere a faculdade, até, de cassar a autorização de funcionar. Fêz-se, no caso, menos que isso: suspendeu-se o funcionamento.

\section{Na Inglaterra e nos Estados Unidos}

Mas é assim também que se pratica na Inglaterra e nos Estados Unidos, como o atestou RUI BARBOSA.

Costuma-se invocar, com relação a êste, em sentido contrário, como leadine-case. o caso Milligan. Mas tratava-se, naquela hipótese, de cidadão condenado à morte por tribunal militar, e que requerera habeas-corpus (o estado de sítio nos EE. UU., como se sabe, consiste na suspensão do privilégio do Writ of habeas-corpus, porque essa suspensão, como ali se tem dito, corresponde à suspensão de todos as direitos), alegando que não se achava no teatro da Buerra. A Suprema Côrte concedeu a medida, e para isto entrou na questão política de determinar qual o teatro da guerra, ou até onde ia ou devia ir a zona de operações.

Mas, a decisão, apesar de se tratar do livramento de um cidadão, de uma condenação à morte, foi tomada por cinco votos contra quatro, êstes últimos do Chief Justice Chase e dos Juizes WAYne, MILLER e Swayne. E, observa Cossa (La constit, degli st. terniti, pág. 63), referindo-se à opinião da minoria :

"La dottrina ha accettato questo modo di vedere ed ha biasimato la sentenza della Corte".

E' que a Côrte, como disse WilloughBy, foi longe de mais chamando a si atribuiçãa politica, exclusiva do Executivo, de reconhecer e marcar a zona de operações (CASTro NuNEs, loc. cit.). Com a minoria ficou a doutrina (GARNER BURGESS) .

A doutrina e a prática são nos Estados Unidos constantes em afastar do Judiciário as questõeg meramente políticas, sujeitas apenas à apreciação dos outros dois poderes: como diz GARNER, citado em CASTRO NunEs (Arquivos, cits., pág. 8), "o domínio do Poder Executivo em tempo de guerra (ou no uso 
das atribuiçóes que lhe confere o estado de emergência (art. 168), como : óbvio) constitui uma espécie de continente negro cujas fronteiras são indoterminadas".

\section{Argumentos improcedentes}

Argumento ad hominem o que tira da dificuldade em responsabilizar, no juízo político, - dos tropecos que geraimente encontra o impeachment.

Pois é isso o que se passa também na Inglaterra e nos Estados Unidos, por causa disso nunca se pensou, ali, em dar aos tribunais atribuições que thes não pertencem.

A respeito do impeachment a que se sujeitam os Lords, disse o mais integro e o mais profundo dos escritores políticos inglêses, Lord Macaulay, que êsse processo "is a' fine ceremony, which may have been useful in the $7_{t b}$. century, but not one from which much good can be expected now' (confirma : KenNy, Outlines of criminal law, 1936, pág. 49.5)

Quanto aos Estados Unidos, disse BRYCE, pitorescamente, que o impeachment constitui, ali, uma formidável peça de artilharia do arsenal do Congresso, mas tão grande e necessitada de tainta pólvora que dificilmente dispara.

$E$ ' possivel seja êsse um defeito inerente às assembléias políticas, que, de resto, não gozam da simpatia do eminente presidente da sociedade impetrante, - qual, referindo-se à Constituição de 1891, disse, com franqueza, aos estudantes, em 15 de novembro de 1942, em discurso, reproduzido a fls. 125 do autos :

"A Carta Política que êles (os constituintes de 91) nos legaram é, na sua parte orgânica, um modêlo de Constituição republicana e.liberal...

Os seus defeitos são inerentes à feição parlamentar que the deram, fruto dos preconceitos reinantes, de que não puderam se libertar os constituintes democratas, empolgados pela eloqüência falaciosa de Rui Barbosa, que dominou, infelizmente, a doutrinação orgânica e construtiva orientada por $J$. de CastiIhos e Demétrio Ribeiro.

Foi assim que a República, fundada sob os mais animadores auspícios, introduziu, desavisadamente, em seu seio o germe letal do parlamentatismo burguês, causa fatal da sua irremediável corruçäa".

A verdadeira causa do aparente insucesso de impeachment reside em que o julgamento de uma política não se faz isolando fatos, mas considerando em conjunto tôda a atuação de um Govêrno. Revestidos da qualidade de julgadores, arrefecidas as paixóes, cessada a tormenta ou vencido o momento difícil, os membros das assembléias legislativas, no fundo de sua consciência de juízes, sentem, pelo geral - e a sensibilidade é, aqui, política - as imensas responsabilidades dos Chefes de Estado, e quão justificadas foram, no quadro político geral do momento, as medidas tomadas, e aquêles mesmos, que antes se levantavam acusadores, são, não raro, os primeiros a lançar na urna o voto da
despronúncia.

Não nos deteremos em examinar o argumento de que, no momento atual, não estando constituída a Câmara, ao Tribunal competiria examinar os ato praticados em estado de emergência.

Esse não é um argumento jurídico, evidentemente. A ser procedente, então os Tribunais, sob o mesmo pretexto, poderiam e até deveriam avocar tôda as atribuições do Legislativo: decretar impostos, organizar o orçamento, conceder anistia, numa palavra, legislar. 


\section{Conclusão}

Tudo o que fica exposto, e que a premência dos prasss não nos permitiu resumir, pode, afinal, ser condensado na ementa seguinte :

Estando o país em estado de emergência (Constituição, art. 186), dos atos do Executivo, por seus agentes praticados nos têrmos do art. 168 da Constituição, não podem conhecer es juízes e triburais, de acôrdo com a disposição categórica do art. 170 da mesma Constituição. Na hipótese, a suspensão (e não đissolução) da associação - das suas reuniões, da sua propaganda, a apreensão dos seus arquivos figuram entre as medidas autorizadas pela artigo 168, e se, na prática da medida, tivesse havido excesso, o Executivo, por Éste excesso, só depois de responter no júzo politico da Câmara dos Deputados (art. 167), poderá ser responsabilizado perante o Judiciário, salvo o disposto no art. 1.525 do Código Civil.

Durante o estado de emergéncia, de nenhum modo, nem direta nem indiretamente, pode o Judiciário apreciar medidas pelo Executivo adotadas em virtude da suepensão de garantias, a ciue se refere o art. 168.

O estado de emergência se distingue do de guerra, porque é regulado no art. 168, e o executor dêle no Distrito Federal é o Chefe de Polícia, como repetida e invariàvelmente têm reconhecido tanto o Tribunal de Apelação como o Supremo Tribunal Federal.

Enfim, não pódendo o egrégio Tribunal conhecer do ato do Executivo, nem, portanto, indagar dos motivos dêle (porque tal indagação importaria em conhecer da medida), a solução a dar ao presente pedido é a de não tomar - Tribunal conhecimento do mesino, por se tratar de medida de ordem e segurança públicas adotada em virtude do estado de emergência, medida política, insindicável pelos tribunais comuns durante o estado de emergência.

Taceat iudex in politicis.

Distrito Federal, 26 de outubro de 1944. - Romão Côrtes de Lacerda, Procurador geral. 